AUSTRALIAN JOURNAL OF BASIC AND
ASSN:1991-8178
EISSN: $2309-8414$

\title{
Doses and Stages of Application of Nitrogen In The Wheat Culture
}

${ }^{1}$ Claudia Manteli, ${ }^{2}$ Douglas Luiz Cordeiro Cappellesso, ${ }^{3}$ Alberto Ricardo Stefeni, ${ }^{4}$ Alexandre Hack Porto, ${ }^{5}$ Marciéli da silva, ${ }^{6}$ BarbaraElis Santos Ruthes, ${ }^{7}$ Gisely Correa de Moura

${ }^{I}$ Department of Agronomy, Teaching Union of Southwest Paraná (UNISEP),Dois Vizinhos, PR, 85660-000, Brazil.

${ }^{2}$ AgronomistEnginee, Rio Grande do Sul Avenue, Dois Vizinhos, PR, 85660-000, Brazil.

${ }^{3}$ Department of Agronomy, Teaching Union of Southwest Paraná (UNISEP),Dois Vizinhos, PR, 85660-000, Brazil.

${ }^{4}$ Department of Agroecosystems, Federal Technological University of Paraná (UTFPR), Dois Vizinhos, PR, 85660-000, Brazil.

${ }^{5}$ Department of Agronomy, Federal Technological University of Paraná (UTFPR), Pato Branco, PR, 85503-390, Brazil.

${ }^{6}$ Department of Agroecosystems, Federal Technological University of Paraná (UTFPR), Dois Vizinhos, PR, 85660-000, Brazil.

${ }^{7}$ Department of Agroecosystems, Federal Technological University of Paraná (UTFPR), Dois Vizinhos, PR, 85660-000, Brazil.

Address For Correspondence:

Alberto Ricardo Stefeni, Department of Agroecosystems, Federal Technological University of Paraná (UTFPR), Dois Vizinhos, PR, 85660000, Brazil.

E-mail: albertostefeni@yahoo.com.br

\section{ARTICLE INFO}

Article history:

Received 12 October 2017

Accepted 22 November 2017

Available online 6 December 2017

Keywords:

Triticunaestivun. Nitrogen

fertilization. Tillering. Booting.

Grouting.

\begin{abstract}
A B S T R A C T
Triticunaestivun is considered a high yield crop, climate factors, handling and nutrition can compromise its yield. Regarding the nutrition of T. aestivun, nitrogen is a limiting factor in production, being one of the most absorbed and required elements. Nitrogen deficiency interferes with the growth and development of the plant, because this element is fundamental in the formation of compounds, like all proteins and nucleic acids. The objective of this research was to evaluate the wheat production components with the application of nitrogen in different doses and times and thus to indicate the appropriate management for the application of this nutrient in the crop under the edaphoclimatic conditions of the Southwest region of Paraná. The experiment was carried out in a randomized block design, with plots subdivided into five replicates. The treatments were composed of four nitrogen doses $\left(0,50,100,200 \mathrm{~kg} \mathrm{ha}^{-1}\right)$ and three application stages (tillering, booting and grouting). The variables evaluated were the severity of the disease $(\%)$, plant height $(\mathrm{cm})$, fresh plant mass $\left(\mathrm{kg} \mathrm{ha}^{-1}\right)$, plant dry mass $\left(\mathrm{kg} \mathrm{ha}^{-1}\right)$, number of growing spikes $\left(\mathrm{m}^{2}\right)$, yield $\left(\mathrm{ha}^{-1}\right)$, number of spikelets per ear, weight of grain and weight of hectoliters. The results were submitted to analysis of variance using the Assistat statistical program for later comparison of the means by regression analysis. There was interaction between treatments for fresh and dry mass varied. The number of cultivars, plant height $(\mathrm{cm})$, spikelets per spike, peaks per $\mathrm{m} 2$ and yield $\left(\mathrm{ha}^{-1}\right)$ were significant for the doses. As to the severity of the diseases and the weight of the hectoliters, they did not present any significance. The highest productivity was obtained with the application of $110.4 \mathrm{~kg} \mathrm{ha}^{-1}$ in the cropping of the crop. However, the need to develop further studies to suit the most ideal phenological stage for nitrogen application as well as the dose.
\end{abstract}

\section{INTRODUCTION}

Belonging to the Poaceae family, Triticunaestivumhas great importance in human and animal feeding since the beginnings of civilizations. Considered a high-yielding crop, climate factors, management and nutrition may compromise its yield. Regarding nutrition of T. aestivun, nitrogen is a limiting factor in production, being one of the elements most absorbed and required.

Nitrogen deficiency interferes with the growth and development of the plant, because this element is fundamental in the formation of compounds, like all proteins and nucleic acids. The symptoms of lack of nitrogen are presented with yellowing, especially in older leaves, called chlorosis. The intensification of their

Open Access Journal

Published BY AENSI Publication

(C) 2017 AENSI Publisher All rights reserved

This work is licensed under the Creative Commons Attribution International License (CC BY).

http://creativecommons.org/licenses/by/4.0/

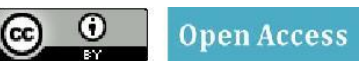

To Cite This Article: Claudia Manteli, Douglas Luiz Cordeiro Cappellesso, Alberto Ricardo Stefeni, Alexandre Hack Porto, Marciéli da silva, BarbaraElis Santos Ruthes, Gisely Correa de Moura., Doses and Stages of Application of Nitrogen In The Wheat Culture. Aust. J. Basic \& Appl. Sci., 11(14): 94-102, 2017 
deficiency can lead to leaf fall (Lacerda, EneasFilho and Pinheiros, 2007).

The application of nitrogen at the right moment and in adequate doses in wheat improves the efficiency of its yield components, maximizing the number of grains per spike and the number of spikes per area (Sangoi et al., 2007). However, the application of nitrogen early or at later stages of the phenology can be less utilized by the plants, consequently affecting the yield components, demonstrating that during the plant cycle there are more suitable phenological stages for the application of this nutrient (Silva et al., 2005).

In wheat cultivation the nitrogen is the mineral element of greater cost. However, it is observed that almost all of the wheat producers in the Southwest of Paraná do not have adequate technical and scientific parameters to follow, and that it is necessary to develop efficient nitrogen application protocols for the crop in question.

In this sense, it is not known about the nitrogen dose and the ideal phenological stage of application so that the best results can be achieved, since there is no specific research for the southwestern region of the state of Paraná.

Thus, the objective of this research was to evaluate the wheat production components with the application of nitrogen in different doses and times and, thus, to indicate the appropriate management for the application of this nutrient in the crop under the edaphoclimatic conditions of the Southwest region of Paraná.

\section{MATERIAL AND METHODS}

The experiment was conducted at the Experimental Farm of União de Ensino do Sudoeste do Paraná UNISEP, located in Dois Vizinhos - PR. The region covers the third paranaense plateau, with an average altitude of $520 \mathrm{~m}$. The predominant climate in this region is the mesothermic wet subtropical (Cfa), according to Koppen classification (Alvares et al., 2014). The soil is classified as red dystroferricnitosol, wavy relief and clay texture (Bherringet al., 2008).

The cultivar of wheat used was Mestre, of the company Biotrigo®. among the main characteristics of this cultivar we can mention the high productivity and industrial quality, due to the high percentage of protein in the grain, besides good gluten strength. Being classified as breeder wheat, it produces gluten without the need for differentiated $\mathrm{N}$ management. It is a medium-cycle cultivar (Biotrigo, 2012).

The sowing of wheat was performed on July $4^{\text {th }}(2014)$, with a density of 450 plants per $\mathrm{m}^{2}$ and spacing between rows of $0,17 \mathrm{~m}$. The seeder used for planting has a continuous flow system. The seeds used were treated using commercial dose of the insecticidal product, systemic based on imidacloprid + thiodicarb.

The experimental area was dried 40 days before planting. The soil was corrected based on soil analysis performed in the area. The base fertilization used was 8-20-18 (NPK), with $292 \mathrm{~kg} \mathrm{ha}^{-1}$.

The statistical design used was a randomized block design, in a split - plot factorial scheme, with five replications. The plots, of $10 \mathrm{~m} \times 3 \mathrm{~m}$ were constituted of three application stages being tillering, booting and grouding. The $2,5 \mathrm{~m} \times 3 \mathrm{~m}$ subplots consisted of treatments with different doses of $\mathrm{N}\left(0,50,100,200 \mathrm{~kg} \mathrm{ha}^{-1}\right)$, using urea as the $\mathrm{N}$ source, thus totaling 15 main plots and 60 subplots.

Cultural managements were made according to the need of the crop. The control of weeds was carried out with herbicide of the class sulfonylurea based on iodosulfuron-methyl at the dose of $0,1 \mathrm{~kg} \mathrm{ha}^{-1}$, insecticides with active principle based on imidacloprid + beta-cyfluthrin $\left(0,75 \mathrm{~L} \mathrm{ha}^{-1}\right)$, and triflumurom $\left(0,03 \mathrm{~L} \mathrm{ha}^{-1}\right)$, respectively, were used to control pest insects such as leafhopper (Metopolophiumdirhodum), green belly bug (Dichelopsmelacanthus) and wheat caterpillar (Pseudaletiasequax). Fungicides based on trifloxystrobin + prothioconazole $\left(0,5 \mathrm{~L} \mathrm{ha}^{-1}\right)$ and trifloxystrobin + tebuconazole $\left(0,75 \mathrm{~L} \mathrm{ha}^{-1}\right)$, together with the soybean oil methyl ester adjuvant $(0,25 \%(250 \mathrm{ml} / 100 \mathrm{~L}$ of water $))$ were used to prevent and control diseases such as wheat rust (Pucciniatriticina), giberela (Gibberellazeae) and brusone (Byriculariagrisea).

In order to compare the effect of treatments on crop development and productivity, disease severity (\%), plant height $(\mathrm{cm})$, fresh plant mass $\left(\mathrm{kg} \mathrm{ha}^{-1}\right)$, dry plant mass $\left(\mathrm{kg} \mathrm{ha}^{-1}\right)$, number of tillers $\left(\mathrm{m}^{2}\right)$, number of spikes $\left(\mathrm{m}^{2}\right)$, yield $\left(\mathrm{ha}^{-1}\right)$, number of spikelets per spike, grain weight and hectoliter weight were measured.

The severity of diseases was evaluated three times, these being always done before the application of chemical products, pulling off three plants per subplot, respecting $0,20 \mathrm{~m}$ of border for further evaluation. For a better understanding of the results, the diagrammatic scale of the EmpresaBrasileira de PesquisaAgropecuária (Embrapa, 2014) was used.

The tiller count was performed at the tillering stage of the crop, along with the first green mass collection, where $0,25 \mathrm{~m}^{2}$ of plants were collected from each subplot, counted manually.

With the aid of a ruler, the height of 20 plants per plot was randomly collected at three stages of development of the tillering, booting and grouting. These collections were carried out according to the application schedule of $\mathrm{N}$.

For the evaluation of fresh mass, $0,25 \mathrm{~m}^{2}$ of plants were collected and packed in paper bags. The data was obtained after the collection with the help of a precision scale. The collected material was taken for drying in a continuous air flow oven where it remained for three days, with a fixed temperature of $55^{\circ} \mathrm{C}$, for later weighing of dry mass. 
The main parameters of productivity were evaluated when the culture presented the physiological maturation, and for the analysis of spikelets per spikes and number of spikes $\left(\mathrm{m}^{2}\right)$, were collected $0,25 \mathrm{~m}^{2}$ of plants, for later manual counting. For final yield, $2,0 \mathrm{~m}^{2}$ of plants were collected from the area of each plot, where they were manually traced and then weighed.

After collecting all data previously mentioned, the hectoliter weight classification was based on the productivity of each plot.

The results were submitted to variance analysis using the software Assistat (Silva andAzevedo, 2009), for later average comparison by regression analysis.

\section{RESULTS AND DISCUSSION}

There were no statistical differences in disease severity, showing that there was no influence of the doses and stages of application of $\mathrm{N}$ in the culture on this variable Table 1 . However, this differs from the results obtained by Tanaka et al.,(2008), who in their evaluation of two wheat cultivars, with the use of nitrogen fertilizations, found plants more susceptible to the attack of diseases with the increase of $\mathrm{N}$ dose, leading to losses and thus reducing productivity.

The high severity of diseases may be related to planting density, which favors the development of favorable environments for development and diseases. According to Baccar et al. (2011), the high density of plants associated with reduced spacing may lead to a higher incidence of diseases. According to EMBRAPA Trigo (2003), the excess of $\mathrm{N}$ in plants promotes a significant growth in the foliar area and increase of the tillering of the culture. This may cause foliar self-shading, resulting in the formation of a micro-climate favorable to the appearance and development of fungi. In addition, this situation can cause fungal infection to be potentiated.

Table 1: Severity of diseases (\%) in wheat crop with the application of doses of N at different stages. Dois Vizinhos - PR, 2015

\begin{tabular}{|c|c|c|c|c|}
\hline & \multicolumn{4}{|c|}{ Doses $\left(\mathrm{kg} \mathrm{ha}^{-1}\right)$} \\
\hline Stages & $0^{\mathrm{NS}}$ & $50^{\mathrm{NS}}$ & $100^{\mathrm{NS}}$ & $200^{\mathrm{NS}}$ \\
\hline Tillering & 40,73 & 40 & 35,53 & 36,6 \\
\hline Booting & 34,87 & 33,27 & 40,33 & 33,07 \\
\hline Grouting & 44,07 & 43,27 & 41,47 & 42,27 \\
\hline
\end{tabular}

NS: Averages not significant by Tukey's test $(\alpha=0,05)$.

$\mathrm{CV}(\%)$ : Coeficient of variation.

The high value of the CV (\%) found (Table 1) is related to the high variation of the data, justifying the nonsignificance of the results analyzed.

For the analysis of the number of tillers per $\mathrm{m}^{2}$, it was observed that there was no interaction between the treatments, however, for $\mathrm{N}$ application in the tillering stage the results were adjusted to a linear regression, with a low coefficient of determination of the equation $(\mathrm{R} 2=0,535)$ Figure 1 . It is shown that the application at this stage presents a greater number of tillers per $\mathrm{m}^{2}$, directly interfering with the final yield, assuming that for each new tiller that completes the crop cycle, a viable spike is obtained.

These results are similar to those found by Zagonel et al., (2002), that also observed an increase in the number of viable tillers per plant with the increase of $\mathrm{N}$, applied in cover, up to the dose of $105 \mathrm{~kg} \mathrm{ha}^{-1}$. The results collaborate with EMBRAPA Wheat (2003), which explains that the application of high doses of nitrogen in wheat provides greater leaf area and increase of tillering. Regarding the tillering of grasses, it is related to the use of these as source of energy reserves that can be used by the main plant in case of necessity due to some stress suffered by the crop. 


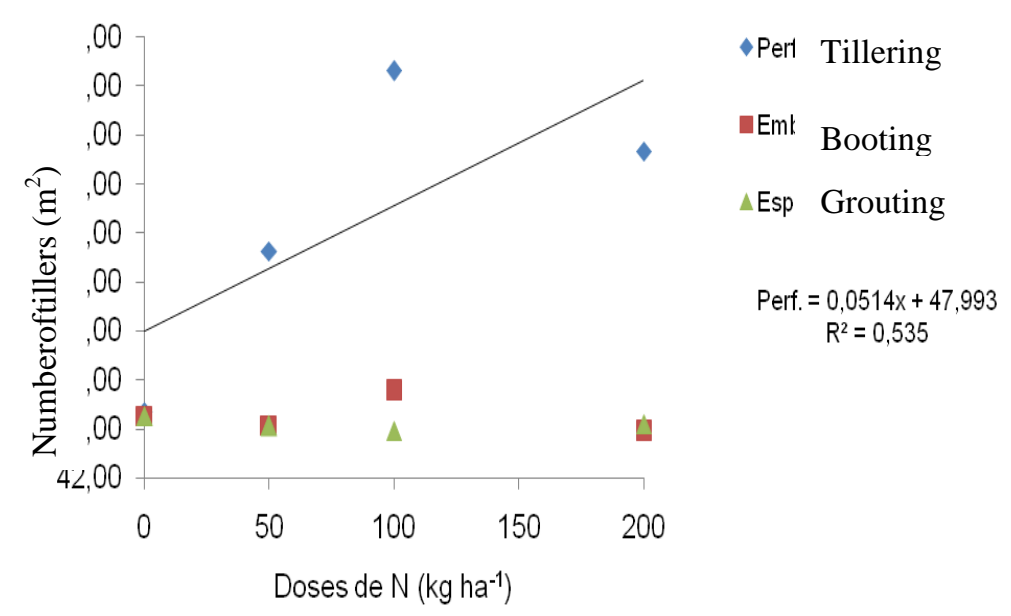

Fig. 1: Number of tillers $\left(\mathrm{m}^{2}\right)$ in wheat crop with the application of doses of $\mathrm{N}$ in different stages. Dois Vizinhos - PR, 2015.

The plant height results were adjusted to a quadratic regression for the application stage of $\mathrm{N}$ in the tillering, reaching its maximum technical efficiency (MET) at the dose of $150 \mathrm{~kg} \mathrm{ha}^{-1}$. Above this, therefore, the variable had no influence on the treatments performed. For the application during booting and grouting stages, there were no statistical differences among treatments Figure 2. Yano (2005), observed significant results for plant height $(\mathrm{cm})$, when the anticipation of the application of $\mathrm{N}$ in wheat favored its development. However, Teixeira Filho et al., (2010) did not found statistical differences with the use of $\mathrm{N}$ in wheat crop, where, regardless of the dose used, there was no increase in plant height, final plant stand, number of grains per spike and mass of 1000 grains.

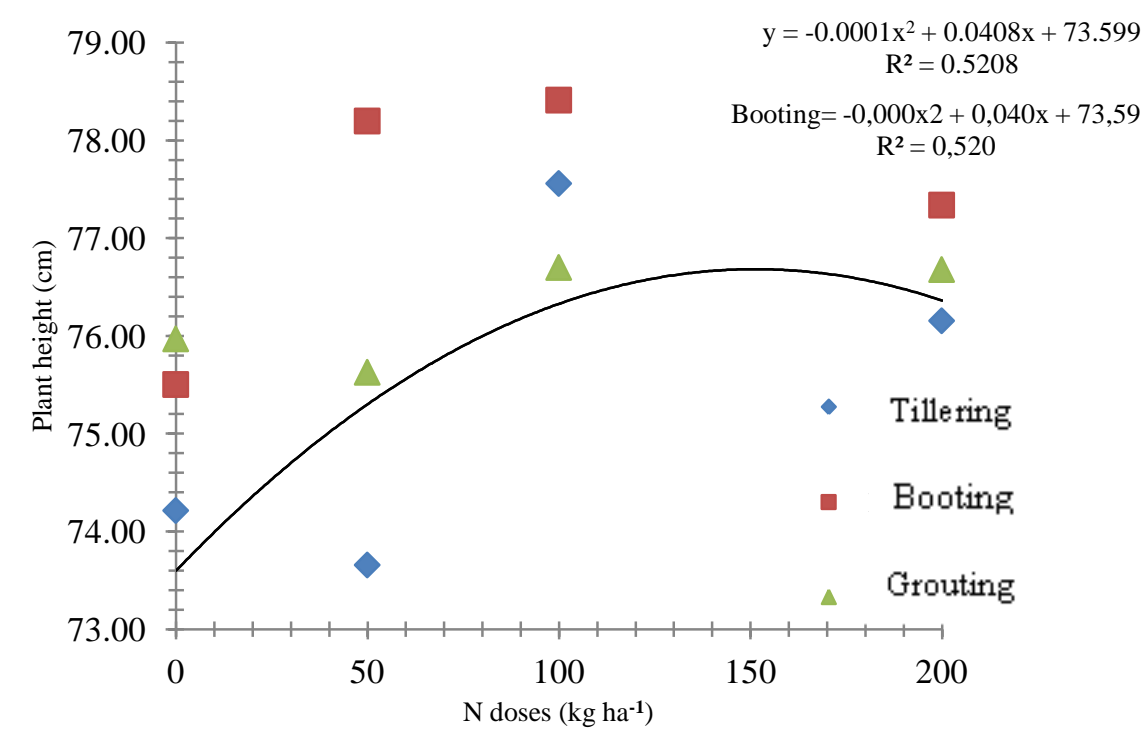

Fig. 1: Plant height $(\mathrm{cm})$ in wheat crop with the application of doses of $\mathrm{N}$ in different stages. Dois Vizinhos PR, 2015

For the variable fresh mass of plant there was interaction between treatments (doses $\mathrm{x}$ stages), so the results were represented with the qualitative factors (stages) in each quantitative factor (doses). The results obtained differed statistically for the stageing treatments during tillering and booting, and for tillering the regression was adjusted in an increasing linear form, that is, increasing the $\mathrm{N}$ dose increases the amount of fresh plant mass by area.

For booting, the values were adjusted to a quadratic regression, where it is observed that this treatment reaches its maximum technical efficiency (MET) with the dose of $114,28 \mathrm{~kg} \mathrm{ha}^{-1}$ Figure 3. For Malavolta (2006), the $\mathrm{N}$ is the major responsible for the plant growth, reflecting in the increase of the leaf area and, 
consequently, in the increase of the mass per plant. This is in accordance with EmbrapaTrigo (2003), which points out that the $\mathrm{N}$ supplement promotes the increase in leaf area index.

For the results of the dry plant mass, interaction between the treatments (doses x stages) also occurred, it is observed that the results referring to the stage of application in the tillering were adjusted to the linear regression and the results referring to the stagebooting to a quadratic regression equation, as was the case with the variable fresh plant mass.

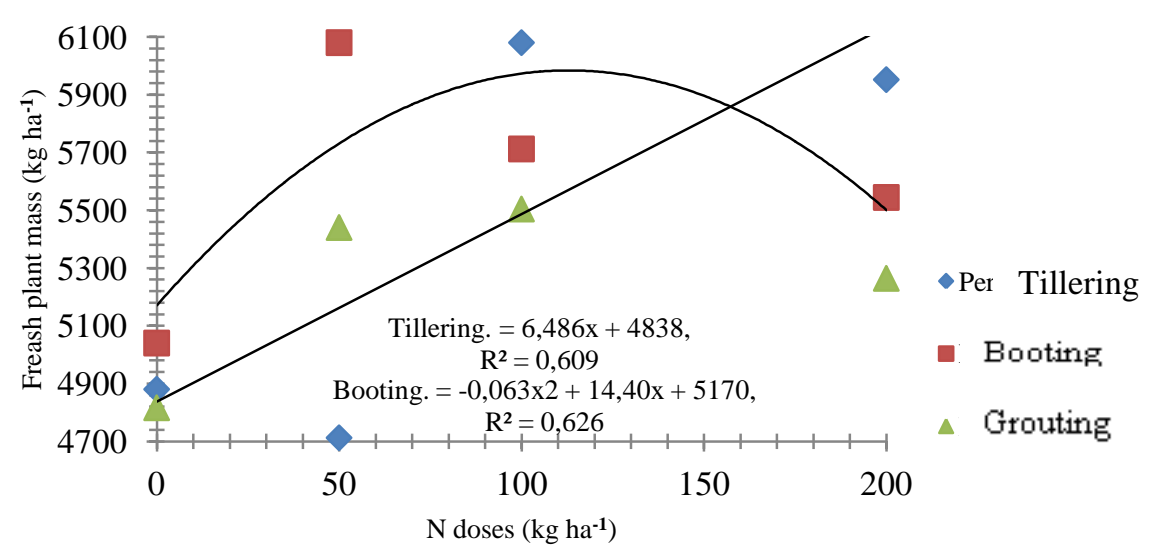

Fig. 2: Fresh plant mass $\left(\mathrm{kg} \mathrm{ha}^{-1}\right)$ in wheat crop with the application of doses of $\mathrm{N}$ in different stages. Dois Vizinhos - PR, 2015.

The fresh mass production figure 4 its maximum technical efficiency found at the beginning of the stage was with the dose of $117.2 \mathrm{~kg} \mathrm{ha}^{-1}$.Similar results were found by Viana and Kiehl (2010), when they worked with different doses of $\mathrm{N}$ and Potassium (K) in wheat growth, where the combined application of higher $\mathrm{N}$ and $\mathrm{K}$ doses increased the dry matter yield of the aerial part.Espindula (2010) verified an increase in dry matter as the $\mathrm{N}$ dose increased, with application of $120 \mathrm{~kg} \mathrm{~N} \mathrm{ha}^{-1}$, yielding a production of 12,000 kg ha-1. On the other hand, Souza et al. (2013) obtained the maximum dry matter production of the aerial part occurred in the dose of $\mathrm{N} 165 \mathrm{mg} \mathrm{dm}^{-3}$.
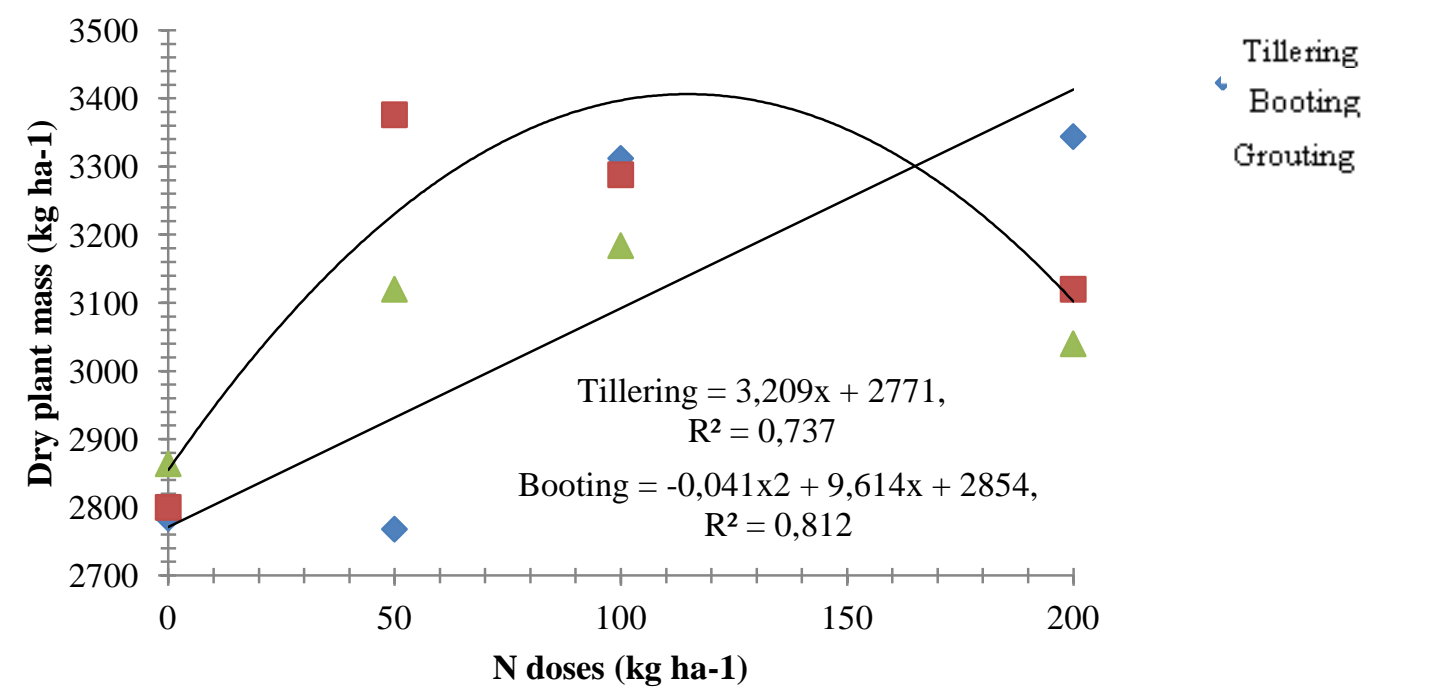

Fig. 3: Dry plant mass $\left(\mathrm{kg} \mathrm{ha}^{-1}\right)$ in wheat crop with the application of doses of $\mathrm{N}$ in different stages. Dois Vizinhos - PR, 2015.

For the number of spikelets per spike the values were adjusted to a linear regression. Regardless of the dose of $\mathrm{N}$ applied, they stood out in relation to the control $\left(0 \mathrm{~kg} \mathrm{ha}^{-1}\right)$ in the three stages evaluated Figure 5 . However, for the dose $200 \mathrm{~kg} \mathrm{ha}^{-1}$, applied in the tillering, $2 \%$ more was obtained than in the booting stage and $3,39 \%$ more in the grouting, which reflects directly in the productivity Figure 5. A similar result was found by Benett et al. (2011), which found a significant effect on the number of spikelets per spike, number of grains per spike and the hectoliter mass, when $\mathrm{N}$ was used as cover. 


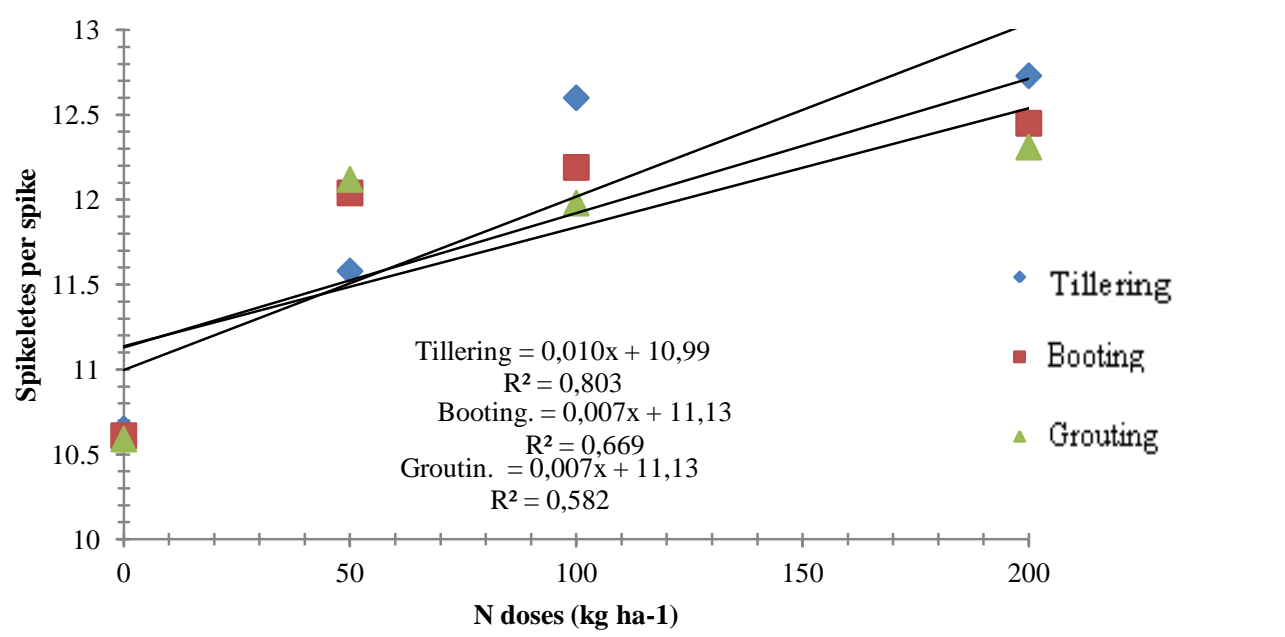

Fig. 4: Number of spikelets per spike in wheat crop with the application of doses of $\mathrm{N}$ in different stages.Dois Vizinhos - PR, 2015

The results obtained regarding the evaluation of the hectoliter weight were not significant. Characterizing the non-influence of this variable in relation to the doses and the stages of application of $\mathrm{N}$ in the culture Table 2.The climatic behavior directly influences wheat quality and yield, which may explain the non-significance of the results obtained since the rainfall during the conduction of the experiment was low which positively influenced the quality of the grains raising the $\mathrm{pH}$ in the different doses of nitrogen.

Similarly, Ormond et al., (2013) stresses the $\mathrm{pH}$ of wheat is what directly reflects the yield of grains in flour or semolina. The higher the $\mathrm{pH}$ the higher the yield, there are three types of wheat and each of these types have a specific minimum value ranging from 72 to 78 (Conab, 2016).

Results were different from those found by Coelho et al. (1998), where the weight of hectoliter, in two years of evaluation of wheat irrigated with application of $\mathrm{N}$ in cover, reduced linearly with the increment of the doses. Experiments conducted by Oliveira et al. (2013) point out that they did not obtain differences with different $\mathrm{N}$ dosages, and these dosages ranged from 0 to $120 \mathrm{Kg}$ ha-1 of $\mathrm{N}$ and the $\mathrm{PH}$ remained at 79 . However, Trindade et al., (2006) obtained a different result, $\mathrm{s}$ as the dosage of $\mathrm{N}$ increases, linearly decreases the $\mathrm{pH}$ of the wheat.

Table 1: Hectoliter weight in wheat crop with the application of doses of $\mathrm{N}$ in different stages. Dois Vizinhos - PR, 2015

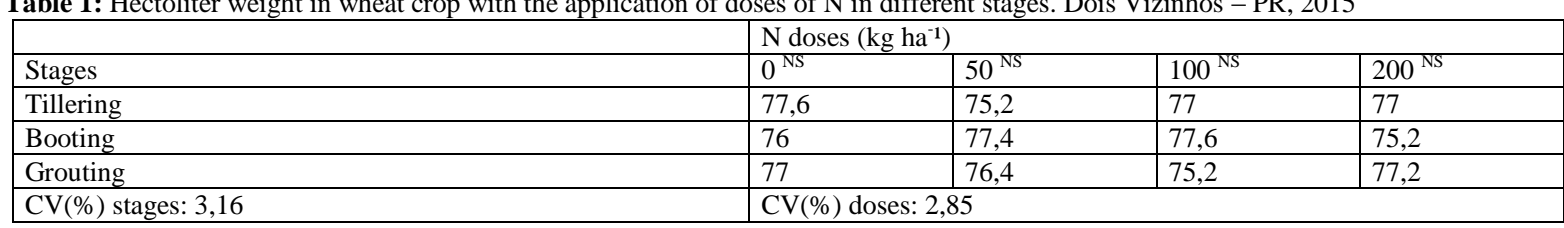

NS: Averages not significant by Tukey's test $(\alpha=0,05)$.

$\mathrm{CV}(\%)$ : Coeficient of variation.

In relation to the number of spikes per $\mathrm{m}^{2}$, linear regressions were adjusted to the data for the grouting stage $(\mathrm{R} 2=0.65)$ and for tillering $(\mathrm{R} 2=0.84)$ Figure 6 . Negative effects of doses of $\mathrm{N}$ were observed. The dose $0 \mathrm{~kg}$ $\mathrm{ha}^{-1}$ presented the highest values of spikes per $\mathrm{m}^{2}$ and the dose of $100 \mathrm{~kg} \mathrm{ha}^{-1}$ showed the lowest results. Based on these results, there is a negative relation between the increase in $\mathrm{N}$ doses and the number of spikes per $\mathrm{m}^{2}$. This can be explained by the fact that the crop in question has undergone a considerable period of lack of rain in the months of August and September, providing a period of stress for the plants when the spikes were in formation.

In turn, Gross et al., (2012) verified when, in addition to sowing density, a linear reduction occurred in the values, a fact explained by the greater intra-specific competition of the resources of the environment, especially in the higher density of sowing evaluated. 


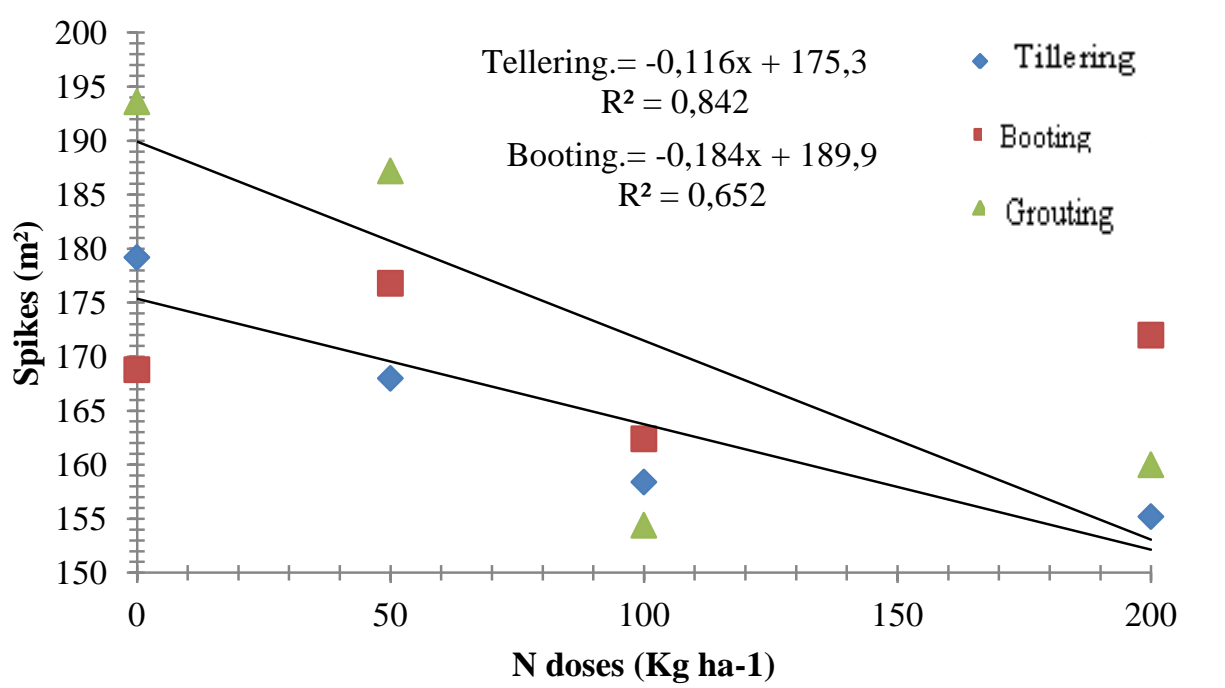

Fig. 5: Number of spikes $\left(\mathrm{m}^{2}\right)$ in wheat crop with the application of doses of $\mathrm{N}$ in different stages. Dois Vizinhos - PR, 2015

When in periods of stress, the tillers can be used as reserves for the plants and do not develop spikes, which confirms the result obtained. Different results were found by Yano et al. (2005), where there was no significance for the number of spikes per $\mathrm{m}^{2}$ applying different doses of $\mathrm{N}$. In relation to the stages of application there were no statistical differences. A similar result to that found by Megda et al., (2009), where no significant effects were verified when the sources and stages of application of $\mathrm{N}$ in wheat in the Cerrado were studied.

For yield $\left(\mathrm{kg} \mathrm{ha}^{-1}\right)$, in the tilleringstage the data adjusted to a linear regression. This fact demonstrates that higher doses of $\mathrm{N}$ could be tested, since $3093,06 \mathrm{~kg} \mathrm{ha}^{-1}$ was produced with the dose of $200 \mathrm{~kg} \mathrm{ha}^{-1}$ of N Figure 7. During the early stages of the crop, the nutrient is needed to increase the maximum number of spikelets per spike and consequently increase productivity (Bredemeier and Mundstock,2001).

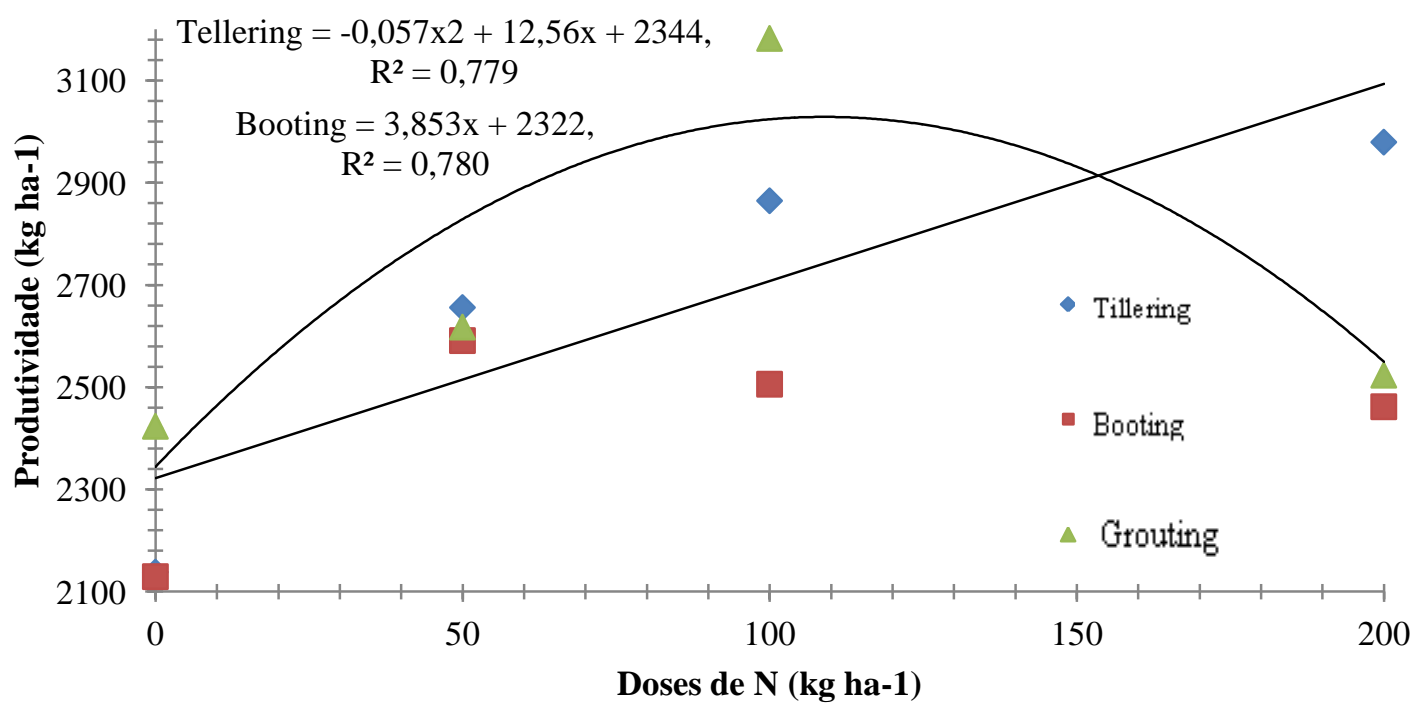

Fig. 6: Yield $\left(\mathrm{kg} \mathrm{ha}^{-1}\right)$ in wheat crop with the application of doses of $\mathrm{N}$ in different stages. Dois Vizinhos - PR, 2015

For the booting stage no regression equation was fitted to the data. For the grouting, a quadratic adjustment was observed, where the maximum technical efficiency (MET) was with the dose of $110,4 \mathrm{~kg} \mathrm{ha}^{-1}$ of $\mathrm{N}$, corresponding to a yield of $3018,54 \mathrm{~kg} \mathrm{ha}^{-1}$. This shows that the use of $\mathrm{N}$ dosages greater than this will not result in gains for the crop at this time under the conditions tested. This result is in agreement with the data of Teixeira Filho et al. (2010), where N rates influenced wheat grain yield in 2006 and 2007, and adjusted to the quadratic functions, with the maximum productivity reached, respectively, with the estimates of 122 and $121 \mathrm{~kg}$ $\mathrm{ha}^{-1}$ of $\mathrm{N}$ under irrigated production conditions. 
If in the tillering this dose was used, only $2747,76 \mathrm{~kg} \mathrm{ha}^{-1}$ would be produced, that is, $270,78 \mathrm{~kg} \mathrm{ha}^{-1}$ less, which demonstrates greater effectiveness in the use of this element in the grouting. This is due to the nitrogen fertilization during grouting to increase the $\mathrm{N}$ availability before filling the grains, and thus, to provide a greater synthesis of proteins, resulting in increased productivity and industrial quality of the grain (Rosso et al., 2014).

The average productivity of the Southwest region of Paraná is $3220 \mathrm{~kg} \mathrm{ha}^{-1}$, but the use of urea is $250 \mathrm{~kg}$ $\mathrm{ha}^{-1}$ max, corresponding to $112,5 \mathrm{~kg} \mathrm{ha}^{-1} \mathrm{~N}$. On the basis of these results, this dose used in the tillering stage would achieve a productivity of $9,3 \%$ less than if used in the grouting stage.

\section{Conclusions:}

The different $\mathrm{N}$ application times did not influence the wheat production parameters, which were influenced only by the different doses tested.

Disease severity was not influenced by the treatments tested under the conditions tested.

The application of $\mathrm{N}$ in the Tillage in the wheat crop linearly increased productivity. Therefore, larger doses should be tested $\mathrm{ha}^{-1}$.

For the variable plant height, the maximum technical efficiency (MET) was found with the dose of $150 \mathrm{~kg}$

There was interaction between the treatments for the green and dry mass variables.

The weight of the hectoliter was not influenced by the treatments tested.

The increase in $\mathrm{N}$ rates reduced the number of spikes per $\mathrm{m}^{2}$ and increased the number of spikelets per spike.

The highest yield was obtained with the application of $110.4 \mathrm{~kg} \mathrm{ha}^{-1}$ in the crop gutting.

However, the need to develop further studies to suit the most ideal phenological stage for nitrogen application as well as the dose.

\section{Future Work:}

To evaluate the application of different doses of nitrogen in the double ring stage - DR and terminal spikelet - TS, as they are phenological stages that have great relation in yield and final quality of the grains in an attempt to maximize productivity.

\section{REFERENCES}

Alvares, C.A., J.L. Stape, P.C. Sentelhas, M.L.J. Gonçalves, G. Sparovek, 2014. Koppen`s Climate Classification Map for Brazil. Meteorologische Zeitschrift, 22(6): 711-728.

BACCAR, R., C. Fournier, T. Dornbush, B. Andrieu, D. Gouache, C. Robert, 2011. Modeling the Effect of Wheat Canopy Architecture as Affected by Sowing Density on SeptoriTritici Epidemics Using a Coupled Epidemic- Virtual Plant Model. Annalsof Botany, 108: 1179-1194.

Benett, C.G.S., S. Buzzertti, S.K. Silva, M.C.M. Teixiera Filho, M. Andreotti, O. Arf, 2011. Aplicação Foliar e em Cobertura de Nitrogênio na Cultura do Trigo no Cerrado. Semina: Ciências Agrárias, Londrina, 32(3): 829-838.

Bhering, S.B., H.G. Santos, C.V. Manzatto, I. Bognola, A.P. Carvalho, O. Potter, M.L.D. Aglio, J.S. Silva, C.E. Chaffin, W. Carvalho Junior, 2008. Mapa de Solos do Estado do Paraná. EMBRAPA/ IAPAR. Rio de Janeiro, p: 74.

Biotrigo Genética. Tbio Mestre, 2012.

Bredemeier, C., C.M. Mundstock, 2001. Estádios Fenológicos do Trigo para a Adubação Nitrogenada em Cobertura. Revista Brasileira de Ciências do Solo, 25: 317-323.

Coelho, M.A.O., M.A. Souza, T. Seddiyama, A.C. Ribeiro, C.S. Sediyama, 1998. Resposta da Produtividade de Grãos e Outras Características Agronômicas do Trigo Embrapa - 22 Irrigado, ao Nitrogênio em Cobertura. Revista Brasileira de Ciência do Solo, Viçosa - MG.

Companhia Nacional de Abastecimento (CONAB), 2015.

Embrapa - 22 Irrigado, ao Nitrogênio em Cobertura. Revista Brasileira de Ciência do Solo, Viçosa - MG, 1998.

Embrapa Trigo. Passo Fundo - RS, 2003.

Embrapa Trigo. Sistema de Produção. Controle das Doenças de Órgãos Aéreos. Passo Fundo, 2014.

Espindula, M.C., 2010. Doses e Formas De Aplicação De Nitrogênio No Desenvolvimento E Produção Da Cultura Do Trigo. Ciência e agrotecnologia, Lavras, 34(6): 1404-1411.

Gross, T.F., A.R. Dias, C. Kappes, L.M. Schiebelbein, J.L. Anselmo, H.V. Holanda, 2012. Comportamento Produtivo do Trigo em Diferentes Métodos e Densidades de Semeadura. Scientia AgrariaParanaensis, 11( $\left.n^{\circ} 4\right)$ : $50-60$.

Lacerda, C.F., J. Enéas Filho, C.B. Pinheiro, 2007. Fisiologia Vegetal- Unidade IV, Nutrição Mineral de Plantas. pp: 70-101. 
Malavolta, E. Manual de nutrição mineral de plantas, 2006. São Paulo: Agronômica Ceres. p: 638.

Marafon, D., 2011. Atividades Realizadas na Produção e Manejo das Culturas de Trigo e Canola. Universidade Tecnológica Federal do Paraná - UTFPR, Pato Branco.

Megda, M.M., S. Buzetti, M. Andreotti, C.M.M. Teixeira Filho, X.M. Vieira, 2009. Resposta de Cultivares de Trigo ao Nitrogênio em Relação às Fontes e Épocas de Aplicação Sob Plantio Direto e Irrigação por Aspersão.Ciência e Agrotecnologia, Lavras, 33(4): 1055-1060.

Oliveira, W.C., L.T.D. Ferreira, R.E. Lorenzeti, R.E. Rutzen, P.H.P. Lima, A.R. Malfato, 2013. Influência das diferentes dosagens de nitrogênio aplicadas em cobertura na cultura do trigo,

Ormond, A.T.S., S.A.J. Nunes, C. Caneppele, S.L.S. Silva, J.T.M. Pereira, 2013. Análise das características físicas de sementes de trigo. Enciclopédia Bioesfera, Goiânia, 9(17): 108-114.

Rosso, O.A.P., J. Hanel, P.A.V. Escosteguy, 2014. Rendimento e Teor de Proteína Bruta em Grãos de Cultivares de Trigo Adubadas com Fertilizantes Nitrogenados Estabilizados. Reunião Sul Brasileira de Ciência do Solo. Fatos e Mitos em Ciência do Solo. Pelotas - RS.

Rural News. O Trigo. Março, 2015.

Sangoi, L., A.C. Berns, M.L. Almeida, C.G. Zanin, C. Schweitzer, 2007. Características Agronômicas de Cultivares de Trigo em Resposta à Época da Adubação Nitrogenada de Cobertura. Ciência Rural, 37 : 15641570 .

Silva, F.A.S., C.A.V. Azevedo, 2009. Principal Components Analysis in the Software Assistat- Statistical Attendance In: WORLD CONGRESS ON COMPUTERS IN AGRICULTURE 7, Reno- NV- USA: American Society of Agricultural and Biological Engineers.

Silva, P.R.F., L.M. Strieder, S.P.R. Coser, L. Rambo, L. Sangoi, G. Argenta, L.E. Forsthofer, A.A. Silva, 2005. Grain Yield and Kernel Protein Content Increases of Maize Hybrids With Late Nitrogen Side-dresses. Scientia Agrícola, Piracicaba, 62: 487-492.

Souza, W.P., B.M.E. Silva, F.A. Schlicchting, C.M. Silva, 2013. Desenvolvimento inicial de trigo sob doses de nitrogênio em latossolo Vermelho de Cerrado. Revista Brasileira de Engenharia Agrícola e Ambiental, 17(6): 575-580.

Tanaka, M.A.S., J.G. Freitas, P.F. Medina, 2008. Incidência de Doenças Fúngicas e Sanidade de Sementes de Trigo Sob Diferentes Doses de Nitrogênio e Aplicação de Fungicida. SummaPhytopathol., Botucatu, 34(4): 313-317.

Teixeira Filho, M.C.M., S. Buzetti, M. Andreotti, O. Arf, S.G.C. Benett, 2010. Doses, Fontes e Épocas de Aplicação de Nitrogênio em Trigo Irrigado em Plantio Direto. Pesquisa Agropecuária Brasileira, Brasília, 45(8): 797-804.

Trindade, M.G., L.F. Stone, B.A. Heinemann, D.A. Cánovas, A.A.J. Moreira, 2006. Nitrogênioe Água como Fatores de Produtividade do Trigo no Cerrado. Revista Brasileira de Engenharia Agrícola e Ambientalv., 10(1): 24-29.

Trindade, M.G., L.F. Stone, B.A. Heinemann, D.A. Cánovas, A.A.J. Moreira, 2006. Nitrogênioe Água como Fatores de Produtividade do Trigo no Cerrado. Revista Brasileira de Engenharia Agrícola e Ambiental, 10(1): 24-29.

Viana, M.E., C.J. Kiehl, 2010. Doses de nitrogênio e potássio no crescimento de trigo. Bragntia, Campinas, 69(4): 975-982.

Yano, G.T., H.W. Takahashi, T.S. Watanabe, 2005. Avaliação de fontes de nitrogênio e épocas de aplicação em cobertura para o cultivo do trigo. Semina: Ciências Agrárias, 26(2): 141-148.

Zagonel, J., S.W. Venancio, P.R. Kunz, H. Tanamati, 2002. Doses de Nitrogênio e Densidades de Plantas com e sem Regulador de Crescimento Afetando o Trigo. Ciência rural, Santa Maria, 32(1): 25-29. 